\title{
State Patronage on Heat and Electricity Markets of the Russian Far East
}

\author{
Olga Dyomina ${ }^{1, *}$, and Svetlana Naiden $^{1}$ \\ ${ }^{1}$ Economic Research Institute of Far Eastern Branch of the Russian Academy of Sciences, Khabarovsk, Russia
}

\begin{abstract}
The paper examines the conditions and goals of state patronage on heat and electricity markets of the Russian Far East. The distinct characteristic of market organization in the region is the lack of a unified energy system, high share of districts with decentralized energy supply, and segmentation of the electricity market. Based on the technological and institutional similarities, scale and form of state patronage, three zones of electricity market were established: market, semimarket, and regulated. The forms of state patronage on heat and electricity markets of the Far East are the following: state regulation of heat and electricity tariffs, setting the tariffs below actual costs, subsidies for providers and consumers of energy, state-sponsored construction of energy capacities. The paper evaluated the scale of patronage on heat and electricity markets and reached the conclusion that without state patronage the Far Eastern consumers of heat and electricity will not be able to purchase energy in market conditions.
\end{abstract}

\section{Conditions for state patronage on heat and electricity markets}

Perfect competition is traditionally viewed as an idealized - and unattainable - model of a market [1]. The extreme case is monopoly, including natural monopoly, that generates the conflict between economic efficiency and competition, where the increasing number of sellers is accompanied by losses due to the lack of economies of scale. The typical examples of natural monopoly are public utilities sphere (electricity, heat, and water supply, etc.), transportation (railways), where the element of monopoly is concentrated in the network $[2,3]$. For a long time, the most acceptable market model for heat and electricity markets was regulated monopoly [4-8]. In this case, state patronage was aimed at containing consumer prices. The idea was that the prices should be as close as possible to the level of marginal costs or provide only normal profit. The fact that energy capacities were owned by the state was an additional argument for state patronage, which allowed substituting external control with internal.

From the end of 1980 s there is an active search of state regulation methods that allow for competition, differentiation of state control forms, and partial privatization in the naturally monopolistic sphere. A new paradigm - market-oriented state regulation - was developed as a transition from direct control over monopolies to regulating their behavior on industry markets. It covers expansion of anti-monopoly regulation to all industries, removal of vertical integration barriers, and clarification of pricing mechanisms. The goal of these measures is creation of the market structure and the mechanism that would allow for competition [9].

This is the way that Russia follows, starting from electricity reform in the beginning of 2000s, and heat supply market reform in 2017 [10]. The main goal of Russian reforms is liberalization of market conditions and elimination of direct state patronage. However, for the Far East ${ }^{\mathrm{a}}$ - the region with harsh climate conditions, a unique system of spatial distribution of economic activity, extremely uneven population density - the state regulation of heat and electricity markets remains. The latter is caused by technical limitations of the local energy system and the impossibility of fostering competition.

\section{State regulation of energy markets}

The peculiarity of the Russian Far East is the lack of prospects of creating a unified energy system. About $40 \%$ of the territories do not have a centralized energy supply systems, primarily remote districts isolated from the electrical and sometimes transport infrastructures of the country. Most energy companies of the region remain vertically integrated and continue functioning as part of the traditional system with state regulation of expenses and tariffs.

Centralized energy supply of the Far Eastern consumers is carried out by the following energy systems:

\footnotetext{
${ }^{a}$ Now and then the Far East is considered to be Far Eastern Federal District (FEFD)
}

\footnotetext{
* Corresponding author: demina@ecrin.ru
} 
- unified energy system of Siberia (UES Siberia), which includes Republics of Buryatia and Transbaikal Krai;

- unified energy system of the East (UES East), which covers Primorsky Krai, Khabarovsk Krai, Amur Oblast, Jewish Autonomous Oblast, and Sakha Republic (Yakutia);

- four technologically isolated energy systems: Sakhalin Oblast, Magadan Oblast, Kamchatka Krai, Chukotka Autonomous Okrug.

The similarity of technological characteristics and institutional conditions of energy market organization in the Far East allows classifying them as a market zone (UES Siberia), a semi-market zone (UES East) and a regulated zone (the four isolated systems). Each zone differs in scale and forms of state patronage.

Unlike electricity supply, centralized systems of heat supply work in individual localities (seldom a large city can have several heat supply systems). The organization of heat supply systems in the Far East largely resembles the one in the rest of the country. The uniqueness is in the low level of energy capacity utilization, complicated logistics, and high costs of delivering fuel into remote and hard to reach parts of the Far East. As a result, economically justified tariffs in some parts turn out to be quite high.

The state patronage on energy supply markets takes different forms:

- state regulation of electricity and heat energy tariffs,

- setting the tariffs bellow actual costs,

- subsidies for producers and consumers,

- state funding for construction of energy facilities (Table 1).

Table 1. Forms of state patronage in the Far East

\begin{tabular}{|c|c|c|}
\hline $\begin{array}{c}\text { UES } \\
\text { Siberia } \\
\text { (market) }\end{array}$ & $\begin{array}{c}\text { UES East } \\
\text { (semi-market) }\end{array}$ & $\begin{array}{c}\text { Isolated energy } \\
\text { systems } \\
\text { (regulated) }\end{array}$ \\
\hline $\begin{array}{c}\text { Preferential tariffs below economically sound for supplying } \\
\text { heat and electrical energy to the general population }\end{array}$ \\
\hline- & $\begin{array}{c}\text { Preferential tariffs on } \\
\text { electricity for industrial- } \\
\text { scale consumers only in } \\
\text { Sakha Republic } \\
\text { (Yakutia) }\end{array}$ & $\begin{array}{c}\text { Preferential } \\
\text { tariffs on } \\
\text { electricity for } \\
\text { industrial-scale } \\
\text { consumers }\end{array}$ \\
\hline $\begin{array}{c}\text { Subsidized fuel delivery for energy producers as part of the } \\
\text { "Northern supply" in remote and hard to reach parts of the } \\
\text { Far East }\end{array}$ \\
\hline \multicolumn{2}{|c|}{$\begin{array}{c}\text { State-sponsored construction of energy } \\
\text { supply facilities }\end{array}$} \\
\hline
\end{tabular}

Semi-market and market zones have elevated costs on energy production, which influences higher prices for consumers. Economic availability of electrical and heat energy for the general population is ensured by setting preferential tariffs below actual costs. It is especially obvious in the de-centralized zone.
For example, population of Khabarovsk Krai pays about $14.4 \%$ of the electricity cost, population of Transbaikal Krai $-5 \%$. The difference is reimbursed by the state through subsidies for producers. This increases the burden on regional budgets. In 2019 the whole of the Far Eastern Federal District (FEFD) saw more than 82 billion rubles spent on subsidies of electricity and heat tariffs, which constituted $8 \%$ of total expenses of all budgets. The regions with the highest costs on electricity (Chukotka Autonomous Okrug, Magadan Oblast, Kamchatka Krai, and Sakha Republic (Yakutia)) also have the highest expenses on reimbursing the tariffs (between $9 \%$ and $17 \%$ of budget expenses). However, despite this support the tariffs on electricity in the Far East are $13 \%$ higher than the country average and twice as high in Chukotka Autonomous Okrug [11].

To ensure the competitiveness of the Far Eastern producers the state introduced a new form of support for the industrial consumers in 2017: subsidies to equalize the tariffs with the average "basic" level in the country. The basic tariff is calculated as the weighted average price of electricity on the markets of other Russian regions excluding isolated parts where energy is more expensive. Since now the consumers in the FEFD pay only the "basic" tariff for electricity, which is lower than the actual costs, the Government of Russia establishes the monetary value of reimbursing the income that energy suppliers in the region did not receive. Annually the Government sets the increase on energy prices for all consumers in the European Russia, the Urals and Siberia to accumulate the necessary means [12]. The Far Eastern energy companies receive compensation through Far Eastern budgets. In 2017-2018 alone, the non-refundable earmarked contributions of "RusHydro" into Far Eastern budgets comprised 59 billion rubles. The volume of subsidies in 2017-2020 is estimated at almost 130 billion rubles. Since no changes into regulation of market conditions are expected in the immediate future, this support measure (expected to be prolonged till 2028) in the authors' opinion will become another regular form of state patronage of Far Eastern consumers [13].

The principles of tariff regulation acting in non-price zone of the Far East do not include the returns on investments, unlike in other parts of Russia where making contracts on providing capacities is the norm. Main energy facility constructions are sponsored by the state: as part of target programs or through purchasing additional stock shares of the main operator "RusHydro".

The Far East has seen the construction of 4 electrical energy supply facilities in 2016-2020: the second stage of Blagoveshchenskoj CHP plant (2016), the first stage of Yakutskoj GRES-2 (2017), Sahalinskaya GRES-2 (2019) and a CHP plant in Sovetskaya Gavan' (launching in 2020). The funds were provided by the federal budget, 50 billion rubles of which were transferred by the government into the authorized capital of "RusHydro". The modernization of existing and construction of new CHPs in the Far East until 2026 is too planned to be funded by the subsidies, which will be sponsored by the increase of prices on wholesale energy markets of Russia. The following constructions are 
planned: Khabarovskaja CHP-4, Yakutskaja GRES-2 (second stage), Artyomovskaja CHP-2, and the modernization of the Vladivostokskaja CHP-2. The total volume of investments is estimated at 171.2 billion rubles, which would increase the burden on the consumers of the unified country-wide energy systems by about 29 billion rubles. As a result, the expenses on electricity carried by the consumers of price zones of Russia who fund the subsidization of Far Eastern tariffs will increase 3-4\% [12].

According to the current rules, subsidies distributed thanks to the new increase do not directly decrease electricity prices for consumers, the share of which in the consumption in the FEFD constitutes $20 \%$. The state uses different measures to support population.

\section{The scale of state patronage of consumers' expenses on public utilities}

For population the state controls the growth of tariffs by annually setting the maximal level of their increase and keeping the level of reimbursement costs below the expenses on production for public utilities, including energy supply.

The level of reimbursement of public utilities costs in 2019 was $92.3 \%$ of established tariffs on average, ranging from the minimal level in Chukotka Autonomous Okrug (56.3\%) to the maximal level in Republics of Buryatia, Transbaikal Krai, Primorskiy Krai, and Amur Oblast (100\%) (Table 2).

Table 2. Formatting The established level of reimbursement of expenses on public utilities by the population, $\%$

\begin{tabular}{|l|c|c|}
\hline & $\begin{array}{c}\text { Directly to } \\
\text { resource } \\
\text { suppliers }\end{array}$ & $\begin{array}{c}\text { Through } \\
\text { management } \\
\text { companies }\end{array}$ \\
\hline Republics of Buryatia & 100.0 & 100.0 \\
\hline Sakha Republic (Yakutia) & 31.4 & 73.3 \\
\hline Transbaikal Krai & 71.1 & 99.9 \\
\hline Kamchatka Krai & 49.2 & 90.8 \\
\hline Primorsky Krai & 76.1 & 100.0 \\
\hline Khabarovsk Krai & 82.3 & 99.4 \\
\hline Amur Oblast & 88.3 & 99.9 \\
\hline Magadan Oblast & 52.8 & 97.5 \\
\hline Sakhalin Oblast & 63.7 & 99.2 \\
\hline Jewish Autonomous Oblast & 97.5 & 95.8 \\
\hline Chukotka Autonomous & 15.0 & 56.3 \\
\hline Okrug & & \\
\hline
\end{tabular}

By encouraging the general population to conclude contracts directly with resource supplying companies, bypassing management companies, the state decreased the level of expense reimbursement of public utilities: to $63.1 \%$ in general in the Far East, ranging from minimal in Chukotka Autonomous Okrug (15.0\%) to maximal in Republics of Buryatia (100\%)

The compensation of difference between established expenses of the population and the actual costs carried by the providers of the utilities (according to economically sound tariffs) rests on the FEFD budgets, which is an additional burden for them.

The regions, for which the state sets a lower level of reimbursement, include the isolated energy systems (Kamchatka Krai, Magadan Oblast, Sakhalin Oblast, Chukotka Autonomous Okrug) and part of UES East (namely, Sakha Republic (Yakutia)). These parts of the FEFD have the highest expenses on generating electricity and heat energy, which is explained by high fuel costs and its delivery to remote districts. Besides, these regions have low population density and unequal distribution of local economic activity, which decreases the utilization of energy capacities significantly and increases the costs of maintaining the infrastructure. Thus, despite keeping the growth of tariffs in check (in 2019 the increment was $4.8 \%$ compared to 2018 level) there is a significant difference in prices on public utilities for population among the FEFD subjects. Even with lower reimbursement level the heat prices range from 1380 rubles per Gcal in Transbaikal Krai to 3805 rubles per Gcal in Kamchatka Krai; electricity prices range from 283 rubles per $100 \mathrm{kWh}$ in Republics of Buryatia to 589 rubles per $100 \mathrm{kWh}$ in Chukotka Autonomous Okrug. Considering limited opportunities for population income growth, especially in remote and economically depressive parts of the Far East, this creates an additional burden on household budgets.

Through the policy of social support in the Far East, the state continues to patronize the population, maintaining the privileges for certain population categories and paying allowance to low-income families. Taking into account the newly attached to the FEFD territories, (Republics of Buryatia and Transbaikal Krai in 2017-2019 the state spent more than 75.6 billion rubles on compensating the costs of public utilities (16.6 billion on subsidies and 59.1 billion on reimbursing privileges). The compensation of electricity and heat supply took about 49.4 billion rubles or $65.2 \%$.

But even with lower tariffs and taking into estimation the subsidies and privileges, the burden on households is higher than the national average values: $10.5 \%$ against $9.6 \%$. For isolated regions, the share of expenses on public utilities is even higher: it is $15 \%$ of all consumer expenses in Kamchatka Krai, 14\% in Magadan Oblast, $12.6 \%$ in Chukotka Autonomous Okrug. And the main share in these expenses is the cost of heat and electricity, which comprises $75-80 \%$ of public utilities costs for northern parts of the region.

It is especially important for the Far East since 15.7\% of its population is considered poor. Sakhalin Oblast has $9.6 \%$ of the population with incomes below the living wage, while Transbaikal has $21 \%$, and the Jewish 
Autonomous Oblast - 24.6\%. The high spatial heterogeneity is reflected in the different purchasing power of the population between and inside the territories of the Far East, which creates additional problems when choosing the methods of state support and its realization. Applying general nation-wide methods in the Far East gives controversial results [14].

In case the expenses on heat and electricity are fully compensated and the limit on maximum share in population expenses is retained, the volume of subsidies (preferences included) in the FEFD will increase from 25.3 billion rubles to 28.1 billion rubles in 2019 prices, which is almost the same as the traditional expenses of regional budgets spent on limiting tariffs. The biggest increase of subsidies will be seen in Chukotka Autonomous Okrug ( $+44.8 \%)$, Sakha Republic (Yakutia) $(+32.4 \%)$, Kamchatka Krai $(+13.9 \%)$, Jewish Autonomous Oblast $(+11.1 \%)$. If the state completely moves away from subsidizing the population, then the voluntary expenses of the population will not exceed $77 \%$ in the Far East in general and will not reach even $60 \%$ in Sakha Republic (Yakutia) and Chukotka Autonomous Okrug.

\section{Conclusions}

As such, all attempts of the state at removing direct regulation and support of consumers and suppliers on the markets of heat and electricity in the Far East are doomed to fail. Without state patronage on the electricity and heat supply market the Far Eastern consumers are not capable of purchasing energy in market conditions. Even with state patronage the tariffs on energy for the Far Eastern consumers of heat and electricity are higher than national average. Without a way of decreasing energy production costs, introducing changes into technological and institutional conditions of energy markets works only through maintaining state patronage. In these conditions, it is logical to expand measures of state support and gradually make temporary measures permanent.

\section{References}

1. E.E. Bailey, W.J. Baumol, Deregulation and the Theory of Contestable Markets, Yale Journal on Regulation, 1, 2, 111-137 (1984). URL: https://digitalcommons.law.yale.edu/cgi/viewconten t.cgi? article $=1010 \&$ context $=$ yjreg

2. S.R. Kim, A. Horn, Regulation policies concerning natural monopolies in developing and transition economies, Discussion Paper of the United Nations Department of Economic and Social Affairs, 28 (1999) URL: https://www.un.org/esa/esa99dp8.pdf

3. A. Pera. Deregulation and Privatisation in an Economy-Wide Context, OECD Studies, 12, 159204 (1989).

4. Coming in from the Cold. Improving District Heating Policy in Transition Economies, OECD, IEA (2006) http://www.iea.org/publications/freepublications/pu blication/cold.pdf

5. L.S. Belyaev, Problems of the Electricity Market, Novosibirsk (2009).

6. Energy Market Experience: Lessons from Liberalised Electricity Markets. OECD, IEA (2005).

7. China. Enhancing the Institutional Model for District Heating Regulation - Outside Perspectives and Suggestions, The World Bank/ESMAP (2012) URL:

https://openknowledge.worldbank.org/bitstream/han dle/10986/17483/823750ESM0ESMA0\%20Box037 9861B00PUBLIC0.pdf? sequence $=1 \&$ is Allowed $=\mathrm{y}$

8. O.V. Dyomina, Evolution of Approaches to Heat Energy Market Regulation, Russian Journal of Economic Theory, 15, 3, 496-506 (2018) URL: https://www.elibrary.ru/download/elibrary 3601165 1 42557656.pdf.

9. $\bar{M}$. Deryabina, Reforming Natural Monopolies: Theory and Practice, Voprosy Ekonomiki, 1, 102121 (2008) URL: https://doi.org/10.32609/00428736-2006-1-102-121.

10. O.V. Dyomina, The District Heating Regulation in Russia: Local Markets' Reaction, Prostranstvennaya Ekonomika = Spatial Economics, 3, 62-82 (2017) DOI: 10.14530/se.2017.3.062-082.

11. O.V. Dyomina, S.N. Naiden, Energy Supply of Khabarovsk Krai: intraregional differentiation and issues of budgetary guardianship, E3S Web Conf., 77, 01007

DOI: https://doi.org/10.1051/e3sconf/20197701007

12. Far East: subsidize or develop, VYGON Consulting, (2018) URL: http://www.bigpowernews.ru/photos/0/0 WCDvVh ha6NGVn5kWR1LH4y7gyC6A1Ily.pdf.

13. The mechanism for leveling energy tariffs in the Far East will be extended until 2028. URL: https://tass.ru/ekonomika/6624747.

14. S.N. Naiden, Social Development in the Far East: Guardianship or Survival, Zhournal Novoi Ekonomicheskoi Associacii, 2(38), 171-178 (2018) DOI: $10.31737 / 2221-2264-2018-38-2-10$. 